\title{
KATEGORI LEKSIKAL IDIOM DALAM BAHASA LAMPUNG
}

\author{
Sulistianah \\ STKIP Al-Islam Tunas Bangsa, Bandar Lampung \\ sulistianah@stkipalitb.ac.id
}

Submit, 28-09-2018 Accepted, 23-12-2018 Publish, 23-12-2018

\begin{abstract}
ABSTRAK
Penelitian ini bertujuan untuk mendeskripsikan kategori leksikal (kelas kata) dalam idiom bahasa Lampung dan makna dalam idiom bahasa Lampung. Metode yang digunakan dalam penelitian ini adalah metode deskriftif kualitatif. Hasil dari penelitian ini ditemukan bahwa idiom bahasa Lampung dapat berbentuk kata kompleks, gabungan kata, dan ungkapan idiomatis, terdapat dua idiom yang berbentuk kata kompleks yaitu penghenguk dan pedatong. Idiom yang berbentuk gabungan kata dapat berupa gabungan nomina + nomina, nomina + adjektifa, nomina + verba, verba + adjektifa dan Verva + verba. Simpulan, berdasarkan perilaku semantik verba yang digunakan dalam bentuk gabungan kata adalah verba keadaan dan verba perbuatan.
\end{abstract}

Kata Kunci: Leksikal, Idiom, Bahasa, Lampung

\section{ABSTRACT}

This research aimed to describe lexical category (word class) and meaning of idiom in Lampung language. Descriptive qualitative was used in this research. The findings showed that idiom in Lampung language could be in form of complex word, word combination, and idiomatic expression. There were two idioms in complex word namely penghenguk and pedatong. Idiom in form of word combination could be a combination of noun+noun, noun+adjective, noun+verb, verb+adjective and verb+verb. The conclusion of the research based on verb semantic attitude that was used in form of words combination like state verb and action verb

Keywords: Lexical, Idiom, Lampung Language.

\section{PENDAHULUAN}

Hampir dalam setiap bahasa memiliki bentuk-bentuk bahasa yang unik yang hanya dimiliki oleh bahasa tersebut. Misalnya, pantun, idiom, cerita rakyat, dan lainlain. Begitu juga dengan bahasa Lampung, bahasa Lampung kaya akan bentuk-bentuk bahasa yang unik yang hanya dimiliki oleh masyarakat Lampung. Missal bentuk idiom. Idiom seringkali digunakan oleh masyarakat Lampung untuk mengungkapkan perasaan atau ekspresi tertentu, missal marah, menyindir, menasihati, ataupun memuji. Salah satu contoh idiom tersebut adalah biyak injak "malas berdiri" bentuk ini digunakan oleh masyarakat Lampung ketika dalam kondisi marah atau kesal. Bentuk ini bermakna 
seseorang yang sangat malas, seseorang yang sangat sulit disuruh untuk bekerja atau melakukan aktivitas.

Idiom juga seringkali digunakan dalam memperindah bahasa dalam situasisituasi tertentu. Masyarakat Lampung juga memiliki banyak upacara adat yang seringkali menggunakan idiom dalam wacananya. Bentuk idiom merupakan bentuk beku yang memiliki makna yang sudah tidak sama dengan makna-makna unsur pembentuknya. Bentuk ini tidak bisa disisipi oleh kata atau morfem lain. Untuk memahami sebuah idiom perlu sekali melihat konteks bahasa dan keadaan budaya masyarakat yang menggunakan idiom tersebut.

Penelaahan terhadap idiom bahasa Indonesia pernah dilakukan oleh Muhammad Suyatno pada tahun 2012 dalam bentuk disertasi. Kajian yang dilakukan mencakup bentuk, ciri, dan makna, ruang lingkup pemakaian, pola pemaknaan, alasan masyarakat Indonesia menggunakan idiom, bagaimana perkembangan idiom bahasa Indonesia. Penelitian lain tentang idiom dalam bahasa Indonesia pernah juga dilakukan oleh Abdul Khak pada tahun 2008 (Balai Bahasa Bandung), kajian yang dilakukan mencakup makna dan struktur. Hasil penelitian tersebut ditemukan tiga jenis idiom dalam bahasa Indonesia, yaitu idiom yang berbentuk kata kompleks, idiom frase dan ungkapan idiomatik.

Adapun terkait dengan penelitian bahasa Lampung, telah ada penelitian terdahulu yang berjudul Kata majemuk dalam bahasa Lampung Dialek A, Kajian Struktur dan Makna. Penelitian ini berbentuk tesis, ditulis oleh Herlina pada tahun 1995. Dalam penelitian ini penulis meneliti ciri-ciri, kompenen, fungsi, dan hubungan antarkomponen kata majemuk bahasa Lampung Dialek A. Metode yang digunakan dalam penelitian ini adalah metode deskripsi dan dikaji melalui teknik distribusional dan komparatif. Dalam penelitian ini penulis mendeskripsikan ciri-ciri kata majemuk bahasa Lampung Dialek A. Penulis juga mengelompokkan kata majemuk Dialek A berdasarkan morfem, kelas kata, jenis kata, fungsi dan hubungan antarkomponen.

Teori yang digunakan dalam penelitian ini adalah, teori-teori yang berkenaan dengan struktur dan makna idiom.Terkait dengan konstruksi, idiom adalah pola-pola struktural yang menyimpang dari kaidah-kaidah bahasa yang umum, bisaanya berbentuk frasa, sedangkan artinya tidak bisa diterangkan secara logis atau secara gramatikal, dengan bertumpu pada makna kata-kata yang membentuknya (Keraf, 2002). 
Terkait dengan struktur idiom Makkai juga berpendapat bahwa idiom adalah sebuah leksem tersendiri.Yang merupakan sebuah entri tersendiri dalam sebuah kamus (Makkai, 2002). Menurut pendapat lainnya Definisi idiom harus dipahami sebagai expresi yang maknanya tidak dapat dipertanggungjawabkan sebagai fungsi komposisi dari arti bagian-bagiannya saat mereka bukanlah bagian dari idiom (Cruse, 1986).

Moeliono (1980) mengatakan bahwa bentukan bahasa yang kaidahnya tidak dapat dirumuskan secara umum dapat dimasukkan kedalam idiom. Sementara itu ahli bahasa lain, Palmer (1983) berpendapat mengenai masalah makna idiom yang berdasarkan kolokasi yang terdapat di antara kata yang membentuk idiom itu. Menurut pendapat palmer, makna idiom dapat digolongkan ke dalam dua jenis, yaitu makna yang legap dan makna yang jelas dan berdasarkan makna itu, dia membagi idiom kedalam dua jenis, yaitu (1) idiom sejati dan (2) idiom sebagian.

Bagi Makkai, karakteristik idiom yang esensial adalah ungkapan itu harus bisa 'menyesatkan' atau tidak tertangkap oleh pendengar yang tidak hati-hati. Makkai (2002), berdasarkan stratum gramatika membuat perbedaan dasar antara idiom leksemik, idiom sememik, dan idiom hipersememik. Idiom sememik disusun oleh lebih dari satu bentuk bebas minimum, sedangkan kata majemuk tidak termasuk idiom. Idiom sememik, seperti peribahasa yang merupakan konstruksi polileksemik, mempunyai makna harfiah dan "moral" tambahan atau pesan terselubung. Idiom jenis ini sampai batas tertentu dapat ditransformasi dan dimodifikasi. Idiom hipersememik, jika ada, maknanya tergantung pada pengunaannya dalam kebudayaan tertentu. Dari uraian itu tampak bahwa idiom bagi Makkai bukan hanya berbentuk frasa, melainkan juga berbentuk frasa atau kalimat, seperti peribahasa.

Berkaitan dengan klasifikasi idiom berdasarkan bentuk salah satunya yaitu berkaitan dengan klasifikasi kelas kata. Adapun yang dimaksud dengan kelas kata yaitu golongan kata yang mempunyai kesamaan dalam perilaku formalnya (Kridalaksana, 2008). Ciri-ciri formal kelas kata berbeda dari satu bahasa ke bahasa yang lain. Secara tradisional kata-kata dikelompokkan atau diklasifikasikan berdasarkan kriteria semantik dan kriteria fungsi 


\section{METODE PENELITIAN}

Metode yang digunakan dalam penelitian ini adalah metode kualitatif, pada metode ini data yang dikumpulkan lebih banyak berupa kata-kata atau gambar dari pada angka-angka (Moleong 2001). Penelitian kualitatif merupakan penelitian yang bersifat alamiah, yang berdasarkan data yang benar-benar ada. Metode deskriptif kualitatif adalah metode yang dapat digunakan peneliti untuk menganalisis dengan melakukan pencarian fakta dengan interpretasi yang tepat. Penyajian data dengan konsep deskriptif artinya peneliti ingin memberikan gambaran-gambaran tentang penggunaan dan struktur yang terdapat dalam idiom. Sumber data berasal dari buku ajar Sastra Lisan Lampung yang dikarang oleh Effendi Sanusi dan Kamus Bahasa Lampung Dialek A yang dibuat oleh Kantor Bahasa Lampung. Upaya memperoleh data yang menggunakan sumber tertulis disebut dengan teknik pustaka.

Hal ini karena sumber data penelitian ini bersumber dari kamus dan buku ajar. Teknik bisa dibagi menjadi dua, yaitu teknik dasar dan teknik lanjutan. Teknik dasar yang dimaksud adalah teknik pilah unsur penentu. Adapun alatnya ialah daya pilah yang bersifat mental yang dimiliki penelitinya. Setelah teknik dasar, penulis menggunakan teknik lanjutan, yaitu berupa teknik catat Hal ini, karena penulis melakukan pencatatan data yang sudah dipilih dari sumber kamus dan buku ajar. Adapun langkah-langkah yang dilakukan dalam pengumpulan data sebagai berikut: (1) membaca sumber data buku ajar dan kamus dengan teliti; (2) menandai bentuk-bentuk yang berupa idiom; (3) mencatat semua unsur yang berisi idiom; (4) menandai idiom yang dan mengklasifikasikan berdasakan bentuknya; (5) mengklasifikasi idiom yang berdasarkan sumber kosakata yang digunakan.

\section{HASIL PENELITIAN}

Berdasarkan hasil penelitian terhadap data, berikut ini adalah beberapa klasifikasi dari data tersebut dan hasil analisisnya berdasarkan struktur idiom, idiom dapat dikelompokkan menjadi tiga yaitu idiom yang berbentuk kata, idiom yang berupa gabungan kata, dan idiom yang berbentuk kalimat. Hasil penelitian seperti pada tabel berikut ini: 
Tabel

Hasil Penelitian Idiom Bahasa Lampung Berdasarkan Kategori Leksikal

\begin{tabular}{|c|c|c|c|c|c|c|c|}
\hline \multirow[t]{2}{*}{ No } & \multirow{2}{*}{$\begin{array}{l}\text { Bentuk kata } \\
\text { kompleks } \\
\text { (Leksemik) }\end{array}$} & \multicolumn{5}{|c|}{ Gabungan kata (sememik) } & \multirow{2}{*}{$\begin{array}{l}\text { Kalimat } \\
\text { (hipersememik) }\end{array}$} \\
\hline & & $\mathrm{N}+\mathrm{N}$ & $\mathrm{N}+\mathrm{V}$ & $\mathrm{N}+\mathrm{A}$ & $\mathrm{V}+\mathrm{A}$ & $\mathrm{V}+\mathrm{V}$ & \\
\hline 1. & Pedatong & $\begin{array}{l}\text { Kelam } \\
\text { pudak }\end{array}$ & $\begin{array}{l}\text { Ngakuk } \\
\text { pudak }\end{array}$ & $\begin{array}{l}\text { Kamak } \\
\text { pungu }\end{array}$ & $\begin{array}{l}\text { Biyak } \\
\text { injak }\end{array}$ & $\begin{array}{l}\text { Cucuk } \\
\text { cabuk }\end{array}$ & $\begin{array}{l}\text { Ibung mak jawoh } \\
\text { anjak ruppun }\end{array}$ \\
\hline 2. & Penghenguk & $\begin{array}{l}\text { Mata } \\
\text { bayuk }\end{array}$ & $\begin{array}{l}\text { Temu } \\
\text { tundun }\end{array}$ & $\begin{array}{l}\text { Paghi } \\
\text { hampa }\end{array}$ & & & $\begin{array}{l}\text { Iwa dacok, wai } \\
\text { mak bulok }\end{array}$ \\
\hline 3. & & $\begin{array}{l}\text { Cecilik } \\
\text { ghaling }\end{array}$ & $\begin{array}{l}\text { Pudak } \\
\text { khacunan }\end{array}$ & & & & $\begin{array}{l}\text { Manjau di salak } \\
\text { tutung }\end{array}$ \\
\hline 4. & & & & & & & $\begin{array}{l}\text { Gegoh tupai } \\
\text { nganik kelapa }\end{array}$ \\
\hline 5. & & & & & & & $\begin{array}{l}\text { Kekalau imbun } \\
\text { jadi muagha }\end{array}$ \\
\hline
\end{tabular}

\section{PEMBAHASAN}

\section{Bentuk dan Makna Idiom Kata Kompleks (leksemik)}

Dari hasil penelitian, penulis menemukan dua idiom dalam bahasa Lampung dialek pesisir yang berbentuk kata kompleks, yaitu penghenguk (anak kesayangan) dan pedatong (oleh-oleh).

\section{Penghenguk}

Penghenguk terbentuk dari kata henguk dengan imbuhan peng-.Imbuhan pengmerupakan alomorf dari imbuhan pe-. Henguk merupakan jenis kata nomina. Secara harfiah kata dasar henguk sendiri berarti (seseorang yang sangat penurut). Ketika mendapat imbuhan peng- menjadi penghenguk yang makna idiomatisnya adalah anak kesayangan. Imbuhan peng bermakna 'memiliki sifat'. Artinya sang anak adalah anak yang memiliki sifat yang sangat penurut kepada kedua orang tuanya. Sehingga anak ini menjadi anak kesayangan.

\section{Pedatong.}

Idiom pedatong terbentuk dari imbuhan pe- dan kata dasar datong (datang). Bentuk kata dasar datong ini secara harfiah berarti muncul atau tiba di tempat yang dituju. Secara idiomatis makna idiom ini adalah sesuatu hal yang ada bersama dengan kedatangan seseorang ataupun barang-barang bawaan yang diberikan kepada orang yang akan dikunjungi, barang-barang ini bisa berupa makanan, ataupun peralatan rumah tangga. 


\section{Bentuk dan Makna Idiom Gabungan Kata (sememik)}

Terdapat lima konstruksi pada Idiom yang berbentuk gabungan kata, diantaranya yaitu nomina + nomina, nomina + verba, nomina + adjektifa, verba + adjektifa, verba + verba.

\section{Nomina+ Nomina}

Konstruksi idiom gabungan bentuk nomina + nomina

\section{Kelam Pudak}

Kelam pudak merupakan salah satu idiom yang terbentuk dari unsur kelas kata nomina + nomina,nomina yang digunakan adalah nomina warna dan anggota tubuh.Makna harfiah dari idiom ini adalah bahwa terjadi perubahan pada wajah seseorang menjadi hitam, sedangkan makna idiomatis idiom ini adalah seseorang yang menjadi marah. Ketika seseorang marah, hal ini diibaratkan dengan suatu keadaan yang membuat raut wajah berubah menjadi hitam atau merah.

\section{Mata Bayuk}

Konstruksi mata + bayuk merupakan konstruksi nomina + nomina, mata merupakan nomina anggota tubuh, bayuk merupakan nomina peralatan. Makna harfiah dari idiom ini adalah lubang-lubang yang ada pada bayuk (keranjang) karena keranjang adalah sebuah peralatan yang dianyam yang tidak terlalu rapat, sehinggga biasanya terdapat lubang-lubang diantara anyaman yang satu dengan anyaman yang lain. memiliki makna seorang laki-laki yang mudah jatuh cinta dan suka melihat perempuan cantik. Mata laki-laki yang seperti ini dikiaskan seperti mata keranjang yang memiliki banyak lubang.Idiom ini biasanya digunakan untuk menyindir seorang laki-laki yang sudah menikah namun masih sering menggoda perempuan lain selain

\section{Nomina + Verba}

\section{Ngakuk Pudak}

Idiom ini terbentuk dari kelas kata verba + nomina.Konstruksi idiom ini dari segi nomina termasuk dalam jenis anggota tubuh, dalam hal verba termasuk verba perbuatan. Makna idiomatis dari konstruksi ini adalah seseorang yang berusaha untuk mencari simpati (perhatian) dari orang lain. Proses melakukan hal-hal yang bertujuan untuk 
mendapatkan simpati inilah yang merupakan yang dikiaskan dengan kata mengambil, sedangkan muka merupakan perumpamaan untuk perhatian atau simpati.

\section{Temu Tundun}

Konstruksi idiom ini terdiri atas verba + nomina. Dari segi perilaku semantisnya verba yang digunakan merupakan verba proses, sedangkan nominanya merupakan nomina anggota tubuh. Kata dasar temu mengandung arti berhadapan atau bersinggungan, kata tundun sendiri berarti punggung. Secara harfiah konstruksi ini berarti dua punggung yang saling bertemu atau dua orang yang saling membelakangi satu sama lain. Jika punggung bertemu punggung maka ini bisa diasosiasikan sebagai ketidak setujuan atau pertentangan. Secara idiomatis makna konstruksi Temu tundun adalah dua orang yang berbeda pendapat atau berbeda jalan pikiran.

\section{Nomina + Ajektiva}

\section{Paghi Hampa}

Paghi hampa merupakan bentuk idiom nomina + adjektifa.Nomina pada konstruksi ini merupakan nomina jenis tumbuhan.Makna dari idiom ini sendiri adalah yang memiliki sifat seperti benda yang disebutkan. Secara harfiahpaghi hampa adalah padi yang sudah dimakan atau dihisap oleh hama padi, sehingga padi ini hanya tinggal kulit luarnya, karena dalamnya sudah kosong atau tidak berisi lagi. Tak ada yang bisa dimakan oleh manusia.Secara idiomatis paghi hampa bermakna perkataan bohong yang tidak memiliki bukti nyata atau tidak ada kebenarannya.

\section{Kamak Pungu}

Kamak pungu merupakan konstruksi nomina + adjektifa. Konstruksi ini terdiri atas nomina anggota tubuh dan adjektifa pemeri sifat. Secara harfiah idiom ini berarti tangan kotor, tangan adalah anggota tubuh yang digunakan oleh manusia untuk memegang ataupun mengambil sesuatu. Kotor merupakan kata sifat yang mengandung makna tidak bersih, jorok, banyak noda atau banyak sampah. Kotor merupakan kata sifat yang mengandung nilai rasa negatif. Secara idiomatis idiom ini mengandung makna orang yang suka mencuri. Secara tidak langsung orang yang suka mencuri dikiaskan dengan orang yang memiliki tangan kotor. 


\section{Verba + Ajektiva}

\section{Biyak Injak}

Biyak injak merupakan konstruksi adjektifa + verba, dari segi perilaku semantisnya kata biyak merupakan jenis adjektifa pemeri sifat sedangkan injak merupakan verba perbuatan. Konstruksi ini secara harfiah bermakna orang yang malas untuk bangun atau berdiri dari duduknya. Secara idiomatis idiom ini bermakna "merasa/perasaan malas untuk bekerja dan melakukan kegiatan lainnya, orang tersebut lebih suka duduk atau berbaring bermalas-malasan.

\section{Verba + Verba}

\section{Cucuk Cabuk}

Idiom cucuk cabuk merupakan konstruksi yang terdiri atas kelas kata verba + verba. Dilihat dari segi perilaku sintaksis kedua verba ini termasuk dalam verba perbuatan. Secara harfiah idiom ini berarti perbuatan yang mencucuk dan mencabut yang dilakukan berulang. Dalam hal ini mencucuk dan mencabut dilakukan dalam waktu yang berdekatan. Secara idiomatis idiom ini bermakna orang yang tidak berpenderian tetap atau mudah mengubah suatu keputusan.

\section{Bentuk dan Makna Idiom Klausa atau Kalimat (hipersememik)}

Ibung mak jawoh anjak ruppun (Rebung tidak jauh dari rumpun bambu)

Dari segi isi kalimat, kalimat ini merupakan merupakan jenis kalimat ingkar. Ditandai dengan kata mak (tidak). Secara harfiah konstruksi kalimat ini berarti tunas rebung muda tumbuh tak akan jauh dari rumpun rebung yang sudah tua. Secara idiomatis makna dari kalimat ini adalah Watak dan sifat anak tidak jauh dari watak dan tingkah laku orang tuanya. Sehingga ungkapan ini seringkali digunakan untuk menyindir para orang tua yang menginginkan anak-anak mereka berkelakuan baik, namun tidak pernah mencontohkan kelakuan baik kepada anak-anak mereka.

Iwa dacok, wai mak bulok (ikan diperoleh, air tidak keruh)

Ungkapan idiomatis ini dalam bahasa Indonesia memiliki arti ikan diperoleh namun tidak membuat air keruh. Idiom ini secara harfiah berarti orang yang mampu memancing tanpa membuat air keruh atau proses memancing yang mendapatkan ikan 
tanpa membuat air disekitarnya menjadi keruh. Hal ini bisa dilakukan oleh orang yang sudah pandai memancing atau orang yang berpengalaman. Sedangkan secara idiomatis peribahasa ini bermakna seseorang yang mampu menyelesaikan suatu masalah dengan baik, tanpa membuat masalah yang lain.

Kekalau imbun jadi muagha (semoga embun menjadi muara)

Dalam bahasa Indonesia idiom ini berarti semoga embun menjadi muara.Secara harfiah idiom ini berarti mengharapkan air embun yang hanya beberapa tetes menjadi banyak beribu kali lipat dengan mengharapkannya menjadi muara. Mengharapkan sesuatu yang sedikit bisa menjadi banyak atau berlipat, pengharapan yang seperti ini dikiaskan sama dengan mengharapkan embun menjadi muara.

\section{SIMPULAN}

Bentuk idiom dalam bahasa Lampung terdiri atas idiom berbentuk kata, berbentuk gabungan kata, dan berbentuk kalimat. Dalam bentuk kata terdiri atas pengheguk dan pedatong. Dalam bentuk gabungan kata terdiri atas nomina + nomina (mata bayuk), nomina + adjektifa (paghi happa), nomina + verba (temu tundun), verba + adjektifa (biyak injak) dan Verva + verba (cucuk cabuk). Jenis nomina yang digunakan terdiri atas nomina anggota tubuh, peralatan hidup, warna, nama tumbuhan, dan nama binatang. Verba yang digunakan terdiri atas verba keadaan dan verba perbuatan. 


\section{DAFTAR PUSTAKA}

Cruse, D.A. (1986). Lexical Semantics. New York: Cambridge University Press.

Keraf, Gorys. (2002). Diksi dan Gaya Bahasa. Jakata: Gramedia

Kridalaksana, Harimurti. (2008). Kamus Linguistik Edisi Keempat. Jakarta: Gramedia Pustaka Utama.

Makkai, A. (2002). Seeking the Nature of Idioms:A Study in Idiomatic Structure. Tim Ifill Haverford College.

Moeliono, Anton M. (1980). Bahasa Indonesia dan Ragam-Ragamnya. Jakarta:Gramedia.

Moleong, Lexy, J. (2001). Metodologi Penelitian Kualitatif. Bandung: Remaja Rosdakarya. 